\title{
The structural and geochemical evolution of the continental crust: Support for the oceanic plateau model of continental growth
}

\author{
Dallas Abbott \\ Lamont-Doherty Earth Observatory, Palisades, New York
}

Walter Mooney

U.S. Geological Survey, Menlo Park, California

\section{Introduction}

The problem of the origin of the continental crust can be resolved into two fundamental questions: (1) the location and mechanisms of initial mantle extraction of the primitive crust and (2) the processes by which this primitive crust is converted into the continental crust that presently exists. We know that Archean continental crust is compositionally distinct from younger continental crust. Archean magmatism was dominantly bimodal, mafic thoeleiitic plus dacitic, heavy rare earth element depleted, in contrast to the dominantly unimodal, roughly andesitic calc-alkaline magmatism on younger crust [Taylor and McLennan, 1985; Condie, 1989]. The problem is whether these compositional differences are primarily due to different mechanisms of crustal extraction from the mantle or to different mechanisms of differentiation and alteration of newly formed continental crust.

Most recent models for the formation of new continental crust postulate that the crust is first extracted from the mantle within the ocean basins, either at island arcs, or at oceanic hotspots (e.g., from mantle plumes) (Table 1). This new continental crust is then tectonically accreted to the edges of pre-existing continents by emplacement along active subduction zones. Thus, the majority of newly accreted continental crustal blocks are rapidly exposed to subduction zone magmatism, which chemically modifies the newly emplaced crust. Because this two-stage process of crustal formation occurs so rapidly, it is very difficult to determine that features of the continental crust are primary features that originated within the ocean basin at the time of extraction from the mantle, and which are secondary features that originated at continental subduction zones. In this paper, we explore some geochemical and geophysical data sets which can provide information on the primary origin and secondary modification of the continental crust.

Copyright 1995 by the American Geophysical Union.

Paper number 95RG00551.

8755-1209/95/95RG-00551\$15.00

\section{Evolution of Subduction Zone Modification}

Recent research has shown that subduction zone magmatism has evolved through time, primarily because the hotter Archean mantle produced thicker oceanic crust that was subducted at a younger age [McCulloch, 1993; Abbott et al., 1994b]. Prior to $2.4 \mathrm{Ga}$, over $95 \%$ of the thick, young oceanic crust subducted shallowly and produced bimodal (mafic thoeleiitic plus dacitic, heavy rare earth element depleted) arc magmatism at convergent margins [Drummond and Defant, 1990; Defant et al., 1991; Martin, 1993; Abbott et al., 1994b]. From $\sim 2.4 \mathrm{Ga}$ to $1.6 \mathrm{Ga}$, the cooling mantle produced increasingly thinner oceanic crust [Abbott et al., 1994a]. The thinner oceanic crust produced an increase in the abundance of steep subduction. Concurrently, the increase in steeply subducting plates produced a rapid increase in the abundance of unimodal (calc-alkaline, roughly andesitic) arc magmatism at convergent margins. At present, the mantle is even cooler and average oceanic crust is thinner than at $1.6 \mathrm{Ga}$. As a result, steep subduction is extremely common, and unimodal magmatism is the most common type of arc volcanism. Thus, it is clear that the mechanisms of continental crustal differentiation at convergent margins have evolved through time, and that this evolution is a direct result of the temporal evolution of mantle temperatures.

\section{Evolution of Crustal Extraction Mechanisms}

The rapid onset and profound temporal evolution of secondary modification of newly formed continental crust produces a geochemical mask which obscures the original method of crustal extraction. For this reason, there is still great controversy over the mode of generation of Archean greenstone belts in particular [Blenkinsop et al., 1993; Bickle et al., 1994] and Archean continental crust in general [De Witt et al., 1992; Padgham and Fyson, 1992; Isachsen and Bowring, 1994]. Although there is general agreement that some Archean greenstone belts were extruded onto pre-existing conti- 
Table 1. Recent papers that propose tectonic models for the origin of greenstone belts with ocean basin-like rocks and ophiolite-bearing terranes. The majority of these terranes are interpreted as island arcs. About one third of the terranes are interpreted as oceanic hotspots or plateaus and/or island arc-plateau composites. Some authors favor neither the plateau model nor the arc model, and simply assert that existing models are inadequate.

\begin{tabular}{|c|c|c|c|c|c|}
\hline Authors & Year & Age & Arc & $\begin{array}{c}\text { Hotspot or } \\
\text { Oceanic Plateau }\end{array}$ & $\begin{array}{l}\text { Existing Models } \\
\text { Are Inadequate }\end{array}$ \\
\hline Fyson and Helmstaedt & 1988 & Archean & Yes & No & No \\
\hline Brouxel and LaPierre & 1988 & Phanerozoic & Yes & No & No \\
\hline Kusky & 1989 & Archean & Yes & No & No \\
\hline Pallister et al. & 1989 & Phanerozoic & No & Yes & No \\
\hline Beard and Barker & 1989 & Phanerozoic & Yes & No & No \\
\hline Box and Patton & 1989 & Phanerozoic & Yes & No & No \\
\hline Haydoutov & 1989 & Late Proterozoic & Yes & No & No \\
\hline Card & 1990 & Archean & Yes & Yes & No \\
\hline Hoffman & 1990 & Archean & Yes & Yes & No \\
\hline Storey et al. & 1990 & Phanerozoic & No & Yes & No \\
\hline Kusky & 1991 & Archean & Yes & No & No \\
\hline Padgham and Fyson & 1992 & Archean & No & No & Yes \\
\hline Davis and Hegner & 1992 & Archean & Yes & No & No \\
\hline Kusky and Kidd & 1992 & Archean & No & Yes & No \\
\hline Boher et al. & 1992 & Early Proterozoic & No & Yes & No \\
\hline Sylvester and Attoh & 1992 & Early Proterozoic & Yes & No & No \\
\hline Blenkinsop et al. & 1993 & Archean & No & No & Yes \\
\hline Desrochers et al. & 1993 & Archean & No & Yes & No \\
\hline Kimura et al. & 1993 & Archean & Yes & Yes & No \\
\hline Isachsen and Bowring & 1994 & Archean & No & No & Yes \\
\hline Poidevin & 1994 & Early Proterozoic & Yes & No & No \\
\hline Bickle et al. & 1994 & Archean & No & No & Yes \\
\hline Dostal et al. & 1994 & Late Proterozoic & Yes & No & No \\
\hline Jackson et al. & 1994 & Archean & Yes & No & No \\
\hline Zhang et al. & 1993 & Phanerozoic & Yes & Yes & No \\
\hline Schandelmeier et al. & 1994 & Late Proterozoic & Yes & No & No \\
\hline
\end{tabular}

nental crust, there is much controversy over the origin of greenstone belts with primitive ocean basin-like rocks and with no evidence for contamination by pre-existing continental crust.

The major theories for the origin of these greenstone belts fall into two classes: juvenile island arcs and mantle plumes [Hoffman, 1990]. As recent work on Phanerozoic continental growth has documented the importance of the accretion of oceanic plateaus [BenAvraham et al., 1981; Pallister et al., 1989; Storey et al., 1990; Kroenke et al., 1991; Richards et al., 1991], a higher percentage of Precambrian greenstone belts with uncontaminated komatiitic volcanics have been interpreted as the result of oceanic plume activity, either in the form of oceanic plateaus or oceanic hotspot islands [Card, 1990; Boher et al., 1992; Kusky and Kidd, 1992; Desrochers et al., 1993; Kimura et al., 1993]. Nevertheless, most greenstone belts and many ophiolite complexes are still interpreted as parts of island arc terranes [Brouxel and Lapierre, 1988; Beard and Barker, 1989; Box and Patton, 1989; Fyson and Helmstaedt, 1989; Haydoutov, 1989; Kusky, 1989; Kusky, 1991; Davis and Hegner, 1992; Sylvester and Attoh, 1992; Zhang et al., 1993; Dostal et al., 1994; Jackson et al., 1994; Schandelmeier et al., 1994] (Table 1).
Although we know that the continental crust is ultimately derived from the mantle, it is also recognized [Taylor and McLennan, 1981] that island arcs cannot reproduce the average composition of the continental crust. Continental crust is significantly more silica rich and more enriched in $\mathrm{Ni}, \mathrm{Cr}$, and incompatible elements than is oceanic arc crust (Ni $25 \mathrm{ppm}, \mathrm{Cr} 60 \mathrm{ppm}$ ) [Taylor and McLennan, 1985]. Although silica and incompatible elements can be added by a combination of convergent margin and alkaline magmatism [Pearcy et al., 1990], these two types of magmatism cannot significantly increase the content of the compatible elements $\mathrm{Ni}$ and $\mathrm{Cr}$. In contrast, volcanic material from the Ontong Java and Manihiki plateaus has enough $\mathrm{Cr}$ and $\mathrm{Ni}$ (Cr 146-290 ppm, Ni 72-185 ppm) [Mahoney et al., 1992] to match average continental crust (Cr 185 ppm, Ni 105 ppm) [Taylor and McLennan, 1985]. These observations could mean that much of the continental crust evolved from oceanic plateaus and that many former oceanic plateaus are misidentified as island arcs. We therefore focus the rest of this paper on determining the origin of primitive ocean basin-like rocks which are preserved on the continents. These rocks are the most likely to preserve a record of the method by which continental crust is originally extracted from the mantle. 


\section{Criteria for Crustal Origin in an Ocean Basin}

Much of the discussion of Precambrian plate tectonics has centered on the ophiolite problem, in particular, the paucity of Precambrian ophiolites with sheeted dikes. To date, only a few early Proterozoic ophiolites with sheeted dikes and mid-ocean ridge-like (MORBlike) rocks have been identified [Helmstaedt and Scott, 1992]. However, the absence of sheeted dikes in most Archean and Early Proterozoic greenstone belts is easy to explain if they are either off-ridge oceanic plateaus or island arcs [Hoffman, 1990]. Sheeted dikes require active seafloor spreading; thus only an Iceland-like plateau has shallow sheeted dikes. Recent theoretical work suggests that near-ridge hotspots will feed the ridge crest if the slope of the base of the lithosphere is relatively steep, that is if spreading rates are $<\sim 3 \mathrm{~cm} / \mathrm{yr}[\mathrm{Kin}$ caid and Gable, 1992]. If spreading rates are $>3 \mathrm{~cm} / \mathrm{yr}$, plateau-forming hotspots do not feed the ridge crest. The minimum seafloor spreading rates inferred for the late Archean are comparable to present-day seafloor spreading rates [Bickle, 1986; Abbott and Menke, 1990; Sleep, 1992]. We infer that most Archean hotspots produced off-ridge volcanic edifices that did not have sheeted dikes except at depths where they would be too metamorphosed to identify. Consequently, a lack of sheeted dikes does not necessarily imply that primitive, ocean basin-like rocks formed on the continents.

\section{Criteria for Crustal Origin in an Island Arc Setting}

Arc magmatism is classically characterized by depletion in high field strength elements, in particular $\mathrm{Nb}$ and Ta. However, recent research has shown that depletion in high field strength elements is not confined to arcs [Perfit et al., 1987; Klein and Karsten, 1994]. In two out of three areas where an oceanic ridge is now subducting, some spreading ridge segments look arc-like in their chemistry. Therefore, depletion in $\mathrm{Nb}$ and $\mathrm{Ta}$ and other types of arc-like chemistry are not unequivocal evidence for origin within an arc.

There is one rock type that apparently forms only at island arcs: low $\mathrm{Ca}$ boninites. Thermal modelling implies that low $\mathrm{Ca}$ boninites $\left(\mathrm{CaO} / \mathrm{Al}_{2} \mathrm{O}_{3}<0.6\right)$ form only when both the overlying plate and the subducting plate are very hot and very young, less than $\sim 4$ million years (m.y.) old at the onset of subduction [Pearce et al., 1992]. The low Ca boninites in the Izu-Bonin arc formed when a transform fault became a subduction zone. Low $\mathrm{Ca}$ boninites result from remelting of mantle depleted by a previous extraction of oceanic crust, and are characterized by extremely low abundances of rare earth elements ( $<5$ times chondritic). Low $\mathrm{Ca}$ boninites have $\mathrm{Nb}$ and $\mathrm{Ta}$ depletions.

In the present-day Pacific, about $15 \%$ of juvenile island arcs (arcs floored by oceanic crust $<180$ m.y. old) contain some low $\mathrm{Ca}$ boninites. In the Archean, the average age of the seafloor was much younger (20 m.y. as opposed to 60 m.y. at present) [Bickle, 1986] and the length of plate boundary was greater [Abbott and Menke, 1990; Sleep, 1992]. A younger age of the seafloor and an increased length of plate boundary would both act to increase the probability of boninite formation. Therefore, we infer that Archean island arcs had high proportions of low $\mathrm{Ca}$ boninites.

\section{Criteria for Crustal Origin at an Oceanic Plateau}

Phanerozoic oceanic plateaus and hotspot tracks are characterized by thick pelagic sedimentary cover and thick $(>20 \mathrm{~km})$ oceanic crust. The crust has high Fe, $\mathrm{Cr}$, and $\mathrm{Ni}$ contents [Klein and Langmuir, 1987]. Unfortunately, boninitic lavas from island arcs also have high $\mathrm{Ni}$ and $\mathrm{Cr}$ contents [Hickey and Frey, 1982]. Therefore, high $\mathrm{Ni}$ and $\mathrm{Cr}$ contents alone are not sufficient to prove that continental crust originated at an oceanic plateau.

The plume heads which form oceanic plateaus are significant sources of excess buoyancy, which promotes plate reorganization like that which occurred during the initial rifting of the North Atlantic near the Iceland hotspot [White and MacKenzie, 1989]. We therefore infer that plate reorganization commonly accompanies plume emplacement. The edges of plateaus are zones of weakness due to the loading of the crust by thick plateau lavas and are logical locations for the formation of subduction zones. If a plate reorganization produces a new subduction zone at the edge of a plateau, the resulting stratigraphy will consist of high Fe tholeiitic basalts, overlain by silicic volcanics with $\mathrm{Nb}$ and $\mathrm{Ta}$ depletions. This stratigraphy in Archean greenstone belts is often interpreted to represent island arc volcanism. However, it could also represent subduction zone volcanism at the margin of a newly formed oceanic plateau. It is also probable that many Archean oceanic plateaus were emplaced close to a convergent margin with ridge subduction, in which case the basalts of the plateau could have arc-like trace element signatures.

\section{Crustal Thickness: New Criteria for the Origin of the Continental Crust}

Many chemical and stratigraphic characteristics are not unique either to island arcs or to oceanic plateaus. Most oceanic plateau lavas and some island arc lavas (boninites) have $\mathrm{Cr}$ and $\mathrm{Ni}$ contents like that of average continental crust [Hickey and Frey, 1982; Taylor and McLennan, 1985; Mahoney et al., 1992]. Both oceanic plateau lavas and island arc lavas can have $\mathrm{Nb}$ and Ta depletions, and other chemical characteristics which were formerly considered diagnostic of island arcs. Furthermore, the plate reorganizations caused by the buoyancy of mantle plume heads may promote the formation of new subduction zones at the margins of oceanic plateaus. Only the formation of low $\mathrm{Ca}$ boninites is unique to island arcs, and not all island arcs have low 
Ca boninites. We therefore need to examine other parameters which might vary significantly between island arcs and oceanic plateaus. We have chosen to model the crustal thickness of island arcs and oceanic plateaus through time and to compare the model results to the observed thickness distribution of the continental crust.

\section{Crustal Thickness Distribution of Continents}

We compiled data on the global distribution of basement ages and plate thickness (Figure 1). We divide the age data into three groups: Archean cratons $(>2.4$ $\mathrm{Ga})$, early Proterozoic cratons $(\sim 1.8-2.4 \mathrm{Ga})$ and noncratonic basement (post $\sim 1.8 \mathrm{Ga}$ ). We use compilations of basement age and the distribution of alkaline rocks that are low degree and high degree partial melts [ $A s h$ wal and Burke, 1989] to define basement age and lithospheric thickness. High degree partial melts (basalts) imply lithosphere less than $140 \mathrm{~km}$ thick. Low degree partial melts (kimberlites and olivine lamproites) imply thicker lithosphere (e.g., cratons). Because diamonds are found only in kimberlites and olivine lamproites, their stability field is an important constraint on lithospheric thickness. The Archean age of some diamonds [Richardson et al., 1984; Richardson et al., 1993] implies long term lithospheric thicknesses of over 200 to $240 \mathrm{~km}$. Our inferences regarding lithospheric thickness are in qualitative agreement with recent tomographic studies [Zhang and Tanimoto, 1993], which can only resolve differences among 5 by 5 degree squares.

Continental crustal thicknesses are from over 500 reliable seismic refraction studies [Prodehl, 1984; Meissner, 1986; Mooney and Braile, 1989; Beloussov et al., 1991; Holbrook et al., 1992]. The data coverage is excellent for North America, Eurasia, and Australia, but Africa and South America are underrepresented. Despite this nonuniform distribution, the available data are adequate to characterize the thickness distribution of Archean, Early Proterozoic, and post $1.8 \mathrm{Ga}$ continental crust.

\section{Mantle Temperature, Crustal Thickness and Lithospheric Buoyancy}

The relationships among the composition of primitive mantle melts, the oceanic crustal thickness, and the mantle temperature are well documented for Phanerozoic ocean basins. Hotter mantle begins to melt at a greater depth, and continues to melt as it rises; colder mantle begins to melt at a shallower depth. The net result is that hotter mantle produces more melting and thicker oceanic crust [Klein and Langmuir, 1987; McKenzie and Bickle, 1988]. Colder mantle melts less and produces thinner oceanic crust [Langmuir et al., 1992]. The composition of the lithospheric mantle beneath the newly created oceanic crust is also affected. Because hotter mantle causes more melting, the oceanic lithospheric mantle loses more garnet and spinel during melting. Because garnet is the most dense phase below 60 to $80 \mathrm{~km}$, the lithospheric mantle formed during hot melting is lighter than the mantle formed during cold melting [Bickle, 1986].

Oceanic crust at pressures $\geq 8-23 \mathrm{~kb}$ reverts to eclogite, which is an extremely dense rock $\left(3.4 \mathrm{~g} / \mathrm{cm}^{3}\right)$. Hotter mantle produces thicker oceanic crust, which would seem to imply that areas of thick oceanic crust should subduct more easily. However, oceanic crust that is more than $\sim 24 \mathrm{~km}$ thick is unsubductable. The reason for this is that the greater thickness of dense eclogite is overwhelmed by the positive buoyancy of depleted lithospheric mantle, which has lost both garnet and iron.

\section{Evidence for a Hotter Archean Mantle}

Archean greenstone belts contain a high abundance of komatiitic lavas, both basaltic komatiites (12-18\% $\mathrm{MgO})$ and komatiites (18-28\% $\mathrm{MgO})$ [Arndt and Nisbet, 1982]. Komatiites are found at only one Phanerozoic locality, Gorgona island, and their maximum $\mathrm{MgO}$ content is 18-19\% [Abbott et al., 1994a]. The liquidus temperature (temperature of the magma near the surface) of a $28 \% \mathrm{MgO}$ komatiite is $\sim 1576^{\circ} \mathrm{C}$, whereas the liquidus temperature of an $18 \% \mathrm{MgO}$ basaltic komatiite is $\sim 1417^{\circ} \mathrm{C}$. Recent work suggests that both the Phanerozoic komatiites and the Archean komatiites represent hotspot magmas [Campbell et al., 1989; Campbell and Griffiths, 1992], implying that mantle hotspots have become cooler through geologic time. Primitive, mid-ocean ridge-like magmas of all types have become cooler through geologic time [Abbott et al., 1994a]. This is consistent with the higher iron content of early Precambrian tholeiitic basalts of all types (arc basalts to MORB-like basalts) [Cattell and Taylor, 1990]. We therefore infer that the higher iron content of Archean tholeiites is best explained by a higher temperature of the entire upper mantle. Higher mantle temperatures in the Archean imply that the Archean ocean basins contained thicker average oceanic crust, thicker island arc crust, and thicker oceanic plateaus.

\section{Modelling Oceanic Plateaus Through Time}

We have constructed a thermal history of the mantle from the liquidus temperatures of the most primitive members of mid-ocean ridge-like suites in greenstone belts and ophiolites. Both the Archean greenstones and Phanerozoic ophiolites produce unimodal distributions that are skewed toward higher temperatures $[A b$ bott et al., 1994a]. The overall liquidus temperature range for both Phanerozoic and Archean MORB-like suites is $236 \pm 31^{\circ} \mathrm{C}$. Liquidus temperatures derived from the inversion of residual depth anomalies on the Pacific plate also show the same skewed, unimodal distribution and the same overall temperature range $[A b$ bott et al., 1994a]. These results imply that both the shape of the liquidus temperature distribution and its 

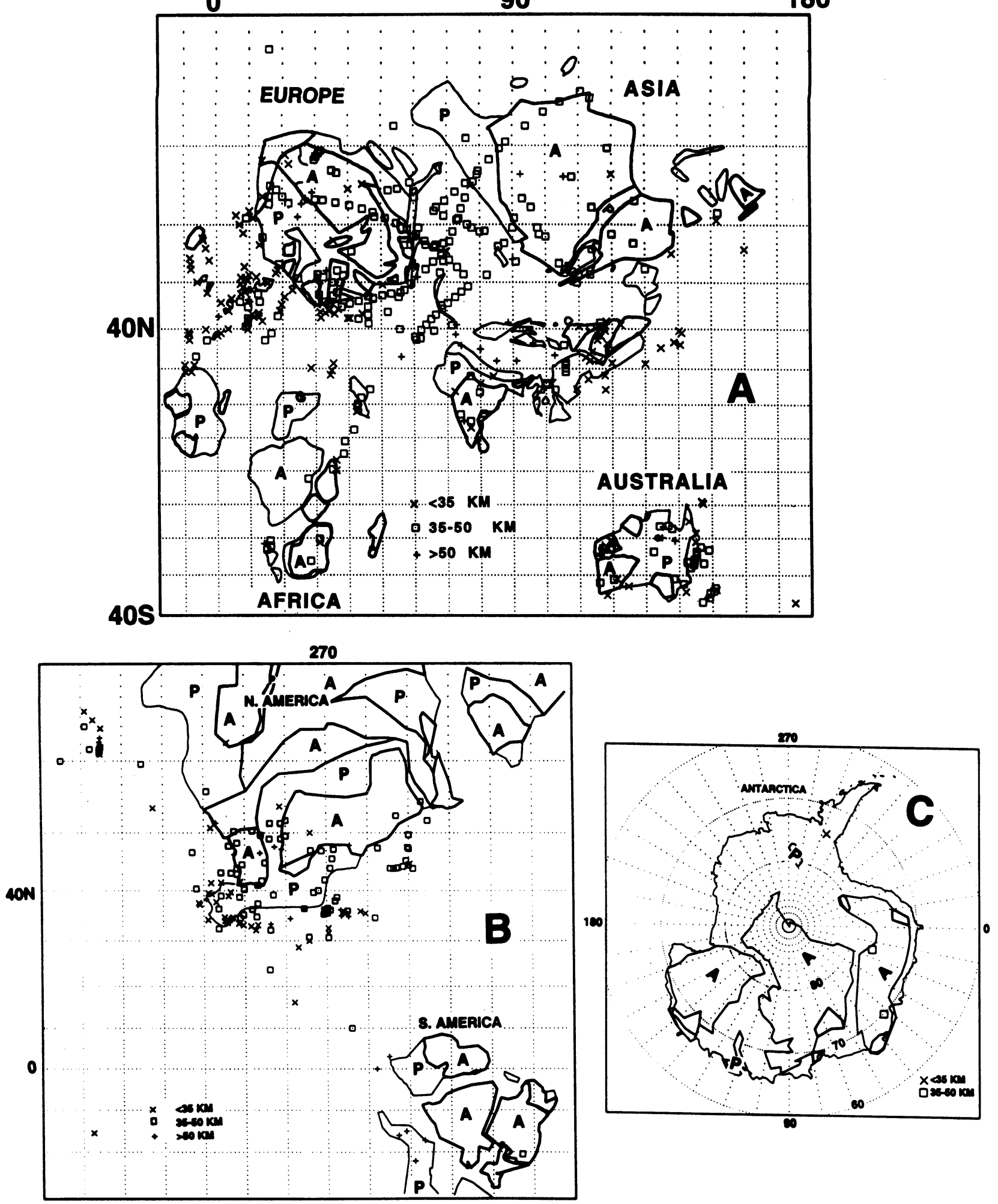

Figure 1. Distribution of basement ages and crustal thickness. Archean (A) cratons $(>2.4$ $\mathrm{Ga}$ ) are outlined in heavy black. Early Proterozoic $(\mathrm{P})$ cratons $(1.8-2.4 \mathrm{Ga}$ ) are outlined. All other crust is post $1.8 \mathrm{Ga}$. Data used to determine basement age [Bennett and DePaolo, 1987; McCulloch, 1987; Naqvi and Rogers, 1987; Wellman, 1988; Hoffman, 1989a; Hoffman, 1991; Patchett, 1992; Smith, 1992; Bogdonava and Bibikova, 1993; Gorbatschev and Bogdonava, 1993; Van Schmus et al., 1993; Rosen et al., 1994]. Crustal thickness data are divided into three groups: Xes, $<35 \mathrm{~km}$; squares, 35 to $50 \mathrm{~km}$; and crosses, $>50 \mathrm{~km}$. Map A: Europe, Asia, Africa, and Australia. Map B: North and South America. Map C: Antarctica. Antarctica is very poorly dated. Known Archean basement in Antarctica has heavy weight outlines, however, Archean basement may encompass the areas with lighter weight outlines and the letter A [Borg and DePaolo, 1994]. 
overall range have not changed with time. By moving the best constrained temperature distribution along a curve defining the temperature change with time, we can model the temporal evolution of oceanic hotspots, island arcs, and average oceanic crust.

The change in mantle temperature versus time is derived using the data in Abbott et al. [1994a], but with a slightly different method. Our previous curve did not go directly through the lowest temperature Archean data point, but slightly above it. However, it makes more sense to fit a curve that goes directly through the lowest temperature point. From our new curve, we estimate that the liquidus temperature of the upper mantle has changed by $\sim 90^{\circ} \mathrm{C}$ since $3.0 \mathrm{Ga}$. Our result is consistent with the recent independent estimate of Galer [1991] that average mantle liquidus temperatures have changed by at most $97^{\circ} \mathrm{C}\left(150^{\circ} \mathrm{C}\right.$ in units of potential temperature, e.g., the temperature of the magma at some reference depth) since $3.5 \mathrm{Ga}$.

The best data on the distribution of mantle temperatures over the last $0.18 \mathrm{Ga}$ derived from an inversion of residual depth anomalies from over 15,000 half degree squares on the Pacific plate [Smith, 1990; Smith, 1993]. The overall shape of the distribution compares well to a much noisier data set derived from the most primitive magmas in each of 37 Phanerozoic ophiolites. In the present-day Pacific, the Ontong Java plateau forms the only sizable area of unsubductable oceanic crust (e.g., over $24 \mathrm{~km}$ thick) [Kroenke et al., 1991] (Figure 2a). Although the Ontong Java plateau has been proposed to be continental because its crust is relatively thick, recent drilling results show no evidence for contamination by continental crust and imply a mantle plume origin for the entire Ontong Java plateau [Mahoney et al., 1993]. Most of the Pacific plate (i.e., all basement aged 0-82 m.y., 102-128 m.y., and 162-178 m.y.) has no implied liquidus temperatures $>1360^{\circ} \mathrm{C}$, thus most of the Pacific plate has crust less than $24 \mathrm{~km}$ thick and will return to the mantle via subduction zones.

We model the crustal thickness of oceanic plateaus through time by taking the liquidus temperature distribution from the Ontong Java plateau and adding a temperature offset in 5 degree steps. We convert the distribution of liquidus temperatures into a distribution of crustal thicknesses using the equations in Abbott et al. [1994a]. We truncate the resulting crustal thickness distribution at the minimum thickness of unrifted continental crust of that age. We then compare the histograms of modelled oceanic plateau crustal thicknesses to actual continental crustal thicknesses.

\section{Comparisons of Plateau Models and Data}

Rather than simply assuming that our thermal history was correct, we found the best fitting temperature change for each age distribution of crust (Figure 2b). Eighty-five percent of Archean crustal thicknesses fit a plateau model with a temperature change of $93^{\circ} \mathrm{C}$

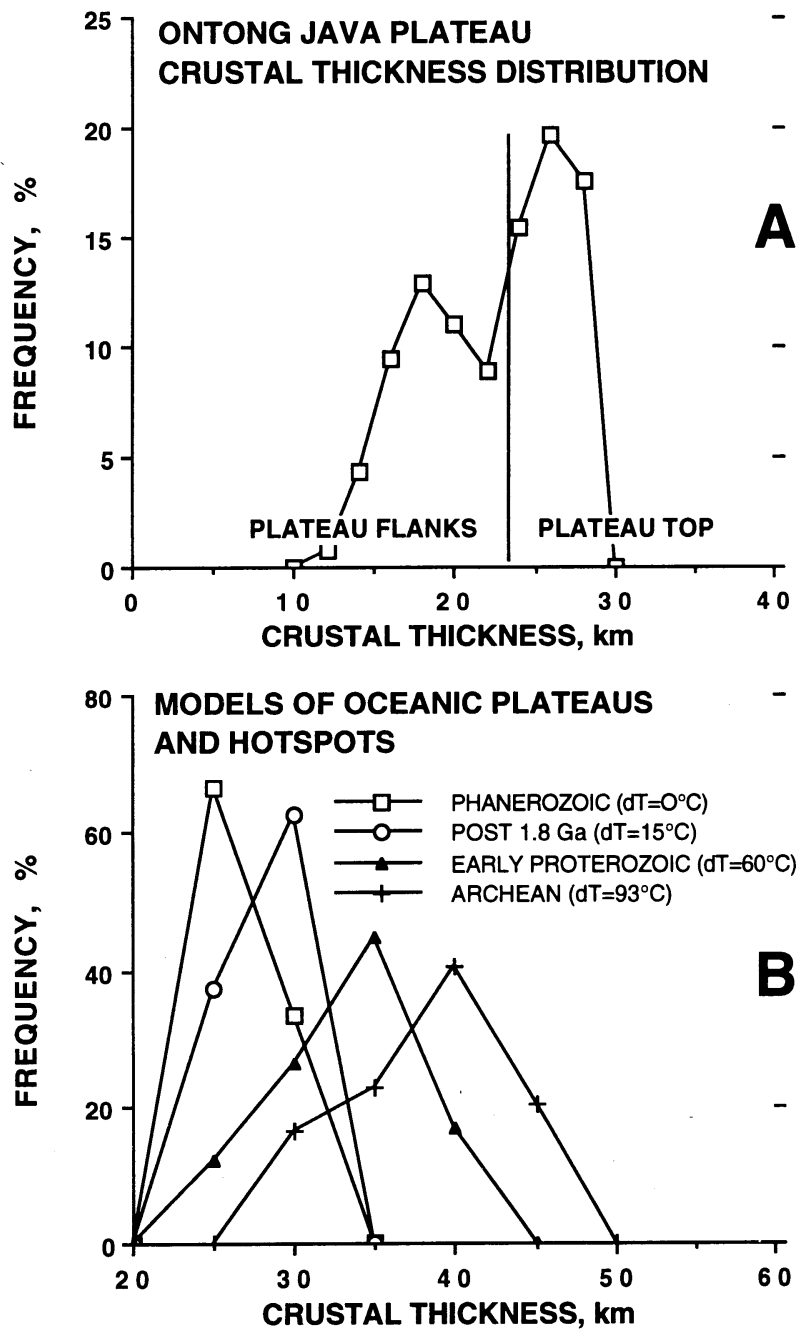

Figure 2. Top: Crustal thickness distribution of the Ontong Java Plateau, as derived from residual depth anomalies. We have calibrated our residual depth anomalies using recently derived estimates of seismic velocity and density from Iceland, with corrections for thermal contraction (W. Menke, D. McKenzie, written comm.). We cannot match previous estimates of a crustal thickness of $37 \mathrm{~km}$ for Ontong Java for any reasonable combination of crustal and mantle densities. We note that continental areas with well determined crustal thicknesses of $37 \mathrm{~km}$ are above sea level. The top of the Ontong Java plateau is about $1 \mathrm{~km}$ below sea level. Bottom: Models of the evolution of crustal thicknesses of oceanic plateaus since the Archean.

(Figure 3d), our estimated temperature change at 3.1 Ga. Sixty per cent of recently accreted Phanerozoic continental crust (within $\sim 500 \mathrm{~km}$ of an active trench) matches a plateau model with a temperature change of $30^{\circ} \mathrm{C}$ (Figure 3a). If we decrease the temperature change to $15^{\circ} \mathrm{C}$, we can match $55 \%$ of the data.

The peak at $40 \mathrm{~km}$ in both the post $1.8 \mathrm{Ga}$ and the Early Proterozoic crustal thickness distributions could be due to a component of reworked Archean crust. We have therefore modelled these two distributions using a composite of juvenile crust plus a component of Archean 

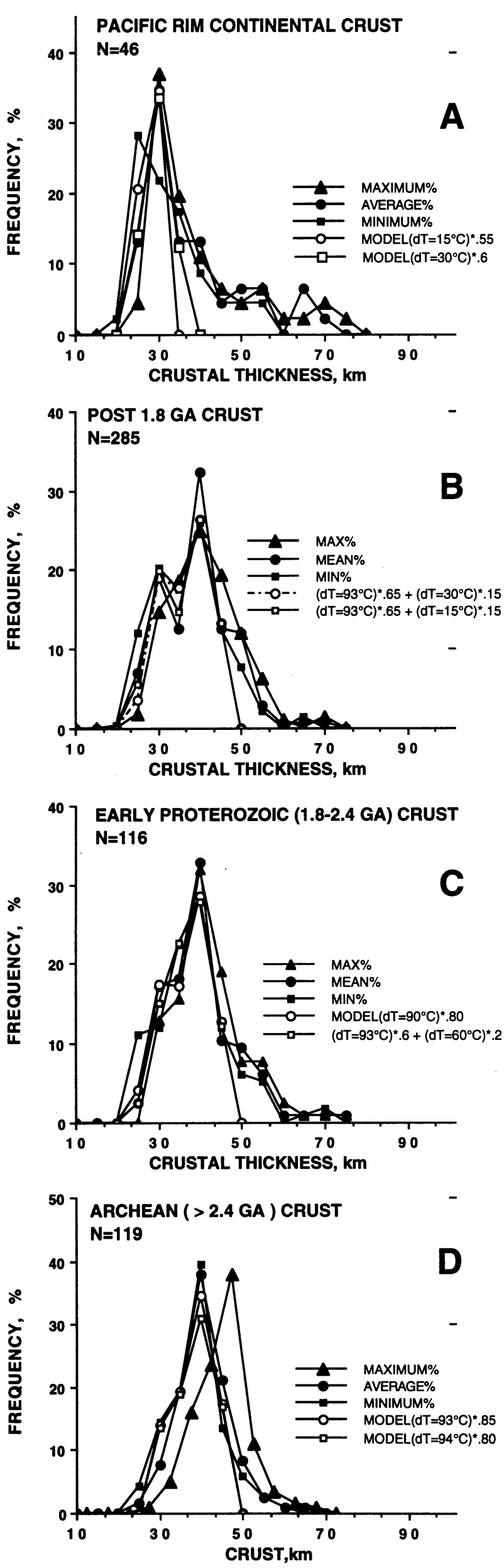

crust (Figures $3 b, 3 c$ ). In order to match the shape of the observed crustal thickness distributions, the composite distributions must have a smaller amount of juvenile crust. Post $1.8 \mathrm{Ga}$ crust best fits a model of $65 \%$ reworked Archean crust $\left(\mathrm{dT}=93^{\circ} \mathrm{C}\right)$ and $15 \%$ juvenile post $1.8 \mathrm{Ga}$ crust $\left(\mathrm{dT}=15^{\circ} \mathrm{C}\right)$. The model is not terribly sensitive to the temperature of the juvenile crust, and a temperature change of $30^{\circ} \mathrm{C}$ will also fit the data. Early Proterozoic crust fits a composite model with $60 \%$ reworked Archean crust $\left(\mathrm{dT}=93^{\circ} \mathrm{C}\right)$ and $20 \%$ juvenile Early Proterozoic crust $\left(\mathrm{dT}=60^{\circ} \mathrm{C}\right)$. Eighty per cent of Early Proterozoic crust also fits a plateau model with a temperature change of $90^{\circ} \mathrm{C}$.

\section{Crustal Thickness of Immature Island Arcs}

We use a melt column model to calculate the crustal thickness which would result from formation of an island arc on top of average oceanic crust: at present, post $1.8 \mathrm{Ga}$, in the Early Proterozoic, and in the Archean The basic idea of a melt column model is that once melting begins at depth in the mantle, melting continues until the magma reaches the base of the lithosphere. Recent work on island arcs supports a melt column model for island arc magmatism [Plank and Langmuir, 1988]. In recent island arc magmatism, the melt column starts at $\sim 100 \mathrm{~km}$, the depth of amphibole breakdown. Melting continues until the mantle reaches the base of the island arc lithosphere. Because old oceanic lithosphere is around $100 \mathrm{~km}$ thick, the greatest volume of magmatism occurs when the arc is young. The total thickness of new crust generated by juvenile island arc magmatism is calculated by multiplying the thickness of the melt column by the percentage of partial melting. Present-day arcs have a maximum of $8 \%$ partial melting [Davies and Bickle, 1991].

Average oceanic crust is $7.1 \mathrm{~km}$ thick, giving a maximum melt column length of $93 \mathrm{~km}$, and a maximum additional thickness of crust added by arc magmatism of $7.3 \mathrm{~km}$, nearly the same as the thickness of pre-existing oceanic crust. This estimate is in qualitative agreement with the observed crustal thicknesses of juvenile island arcs in the Pacific. From residual depth anomalies, we calculate a mean crustal thickness beneath 91 active arc volcanos of $15.8 \pm 1.7 \mathrm{~km}$. The distributed crustal thickness along the entire arc will be much less. Using our observations of crustal thickness, juvenile island arcs at present have (at most) an average crustal thickness of 2.2 times the thickness of average oceanic crust.

Figure 3. Histograms of the minimum, maximum and average distribution of crustal thickness compiled using error bars of $\pm 2 \mathrm{~km}$ for each observation of crustal thickness. Models are of the crustal thickness distribution of an oceanic plateau of a given age. Each model is multiplied by a fraction which reduces peak height and provides an estimate of how well the data fits the model: (A) post $1.8 \mathrm{Ga}$ crust within $500 \mathrm{~km}$ of a trench, (B) all post $1.8 \mathrm{Ga}$ crust, (C) $1.8 \mathrm{Ga}$ to $2.4 \mathrm{Ga}$ (early Proterozoic) crust and (D) $>2.4 \mathrm{Ga}$ (Archean) crust. 
Thicker oceanic crust decreases the length of the melt column. Therefore, we estimate post $1.8 \mathrm{Ga}$ and Early Proterozoic melt column lengths of 91 and $87 \mathrm{~km}$, respectively. In the Archean, the base of the arc melt column rose to about $80 \mathrm{~km}$, due to the combined effects of higher temperatures decreasing the depth of amphibole dewatering [Cloos, 1993] and a predominance of shallow subduction. Therefore, the Archean arc melt column was $\sim 63 \mathrm{~km}$ long. Using these changes in melt column length, juvenile arc crust was $2.2,2.1$, and 1.5 times the average thickness of oceanic crust for post 1.8 $\mathrm{Ga}, 1.8$ to $2.4 \mathrm{Ga}$, and before $2.4 \mathrm{Ga}$, respectively.

Using the thickness of average oceanic crust calculated for mantle temperature changes of $30^{\circ} \mathrm{C}, 60^{\circ} \mathrm{C}$, and $93^{\circ} \mathrm{C}$, juvenile island arcs built on average oceanic crust had crustal thicknesses of 21, 27, and $26 \mathrm{~km}$ for post $1.8 \mathrm{Ga}$ crust, Early Proterozoic crust, and Archean crust, respectively. Our data set shows minimum thicknesses of unrifted continental crust of 24,26, and 28-30 $\mathrm{km}$ for post $1.8 \mathrm{Ga}$, Early Proterozoic, and Archean crust. Except for early Proterozoic time, there is no unrifted continental crust whose thickness matches the expected thickness of juvenile island arcs. Less than $3 \%$ of Early Proterozoic crust is $\leq 27 \mathrm{~km}$ thick. Based on the observed crustal thickness distribution of continents, immature island arcs are not now, and were not ever, a significant source of new continental crust. The one caveat to this result is that it does not include island arcs which have interacted with hotspots. These island arcs will have crustal thicknesses like oceanic plateaus and hence will be indistinguishable from them.

\section{Discussion of Modelling Results}

Our modelling results seem to require that most continental crust originated as oceanic plateaus. We can test the validity of these results in several ways. The first is by searching for Precambrian low $\mathrm{Ca}$ boninites, which can only form in island arcs. Although there are several claims of Precambrian boninites, there is only one known occurence of low $\mathrm{Ca}$ boninites: the Boguin greenstone belt [Poidevin, 1994]. The Boguin boninites occur with komatiites, suggesting some later involvement with a hotspot. The Boguin greenstones are Early Proterozoic in age, which is the time period for which our modelling suggests a modest number of accreted arcs.

A second test is to estimate the mean ages of the plateau crust using the temperature changes that we derived from our models. Using our thermal history model, temperature changes of $30^{\circ}, 60^{\circ}$, and $93^{\circ} \mathrm{C}$, imply mean basement ages of $1.3 \mathrm{Ga}, 2.25 \mathrm{Ga}$, and 3.06 $\mathrm{Ga}$. When we looked at our data base, we found that most of the Archean data comes from older Archean blocks, e.g., the Pilbara (3.2-3.5 Ga), Siberia (3.0-3.1), the Wyoming craton (3.1-3.6), the Ukrainian shield (2.9-3.6), peninsular India (3.0-3.1), southern Africa (3.0-3.5), and the northern Baltic shield (2.6-3.4). The ages are the estimated mantle extraction age (Figure
1). Crustal thickness should correlate to the age of mantle extraction, not the age of the last metamorphism. Therefore, our model results for Archean age crust are self-consistent. For younger terranes, the apparent ages for temperature changes of $30^{\circ} \mathrm{C}$ and $60^{\circ} \mathrm{C}$ are 1.3 and $2.25 \mathrm{Ga}$. Geochemists infer that most of the continental crust was formed early on, and that there has been a great deal of reworking of that earlier formed crust [McDermott et al., 1989; Toft et al., 1989; Salisbury and Fountain, 1990]. There is widespread evidence for reworking of older basement and for its incorporation within younger orogens. Some examples are the circa $2.0 \mathrm{Ga}$ crust of the Arequipa massif [Dalziel and Forsythe, 1985], and of the Mohave terrane [Bennett and DePaolo, 1987]. Both of these terranes are within $500 \mathrm{~km}$ of an active trench and could appear in Figure $3 \mathrm{a}$. Therefore, mean apparent ages of $1.3 \mathrm{Ga}$ and 2.25 Ga seem entirely consistent for the post $1.8 \mathrm{Ga}$ and 1.8 $2.4 \mathrm{Ga}$ distributions of continental crustal thickness.

A final test is the history of continental growth. Juvenile island arcs are created at a relatively uniform rate, yet isotopic data indicate that continental growth has been episodic [McLennan and Taylor, 1991; McCulloch and Bennett, 1993]. In contrast, oceanic plateaus like the Ontong Java do not form at a uniform rate, but are concentrated within geological intervals like the Cretaceous long normal magnetic epoch (e.g., the superplume event) [Larson, 1991]. The Cretaceous long normal was an interval of rapid seafloor creation, which produced a large sea level high. Based upon relative amplitudes of sea level highs, the last interval of similar intensity occured at the Cambrian-PreCambrian boundary [Vail and Mitchum, 1979]. Therefore, there has been an interval of about 450 m.y. between Phanerozoic "superplume" events. These events are most likely associated with the coalescence and breakup of supercontinents [Hoffman, 1989b]. We do not know the interval between all Precambrian supercontinents, but we do know that periodic intervals of increased oceanic plateau formation would produce episodic continental growth [Stein and Hofmann, 1994].

Although our model results seem to be self consistent, they are heavily dependent upon the extent to which the preserved crustal thicknesses reflect the crustal thickness at the time when the crust formed. Many factors can change crustal thickness. Rifting and erosion can decrease crustal thickness. Basaltic underplating can increase crustal thickness [Fyfe, 1993]. Many areas of post-Archean basement have basaltic lower crustal xenoliths that may represent crustal addition by later basaltic underplating [Ruiz, 1992; Downes, 1993]. However, accurate dating of lower crustal rocks is difficult [Rudnick and Cameron, 1991]. Recent, high precision age data indicate that most basaltic crustal xenoliths are the same age as the overlying crust [Wendlandt et al., 1993]. Therefore, the basaltic composition of most post-Archean lower crust is a primary feature and there may have been much less underplating than previously assumed. 
Himalayan collisions and pluton intrusion at convergent margins will also increase crustal thickness [Bruce et al., 1989; Grocott et al., 1994]. It is therefore important to determine the relative importance of these processes in different areas. There is limited evidence for magmatic underplating and Himalayan-type collisions in areas of Archean basement. This may be why most Archean crustal thicknesses match the crustal thicknesses expected for an Archean oceanic plateau. However, the evidence for limited Archean underplating is seismic [Durrheim and Mooney, 1991], which means that olivine cumulates would be missed. Archean lithosphere is also rigid and difficult to deform, which would limit the effects of Himalayan-type collisions. Therefore, Archean continental lithosphere may have the right characteristics to preserve its original Moho and to preserve a record of its origin as an oceanic plateau.

A final caveat is that neither island arcs nor oceanic plateaus are high enough in silica or in incompatible elements to match the average composition of continental crust. Furthermore, the seismic structure of the upper continental crust does not match either an island arc or a plateau model. Therefore, the original crustal structure of accreted terranes must be modified soon after the crust is formed. Except for large plateaus, recently accreted oceanic crust is immediately exposed to convergent margin magmas, which will act to differentiate it, increase its silica content, and to increase its store of incompatible elements. Therefore, rapid modification of new continental crust is nearly inevitable.

\section{Conclusions}

Currently, the most popular model for the initial formation of continental crust is the island arc model. However, recent geochemical and geophysical data more strongly support the mantle plume model. Primary extraction of crustal material from the mantle by plumes can account for more than $80 \%$ of the observed distribution of continental crustal thicknesses. In contrast, nearly all measured crustal thicknesses are too thick to fit models involving juvenile island arcs, implying that most juvenile island arcs are subducted. Subduction of most juvenile island arcs is consistent with two other geological observations: the paucity of low $\mathrm{Ca}$ boninites in the geologic record, and the episodic nature of continental growth. Also, mantle plumes generate crust with the right $\mathrm{Cr}$ and $\mathrm{Ni}$ contents, whereas island arc crust contains insufficient $\mathrm{Cr}$ and $\mathrm{Ni}$. However, neither the arc nor the oceanic plateau model fully explains all of the observed characteristics of the continental crust. It is clear that some mantle plumes have interacted with island arcs (and vice versa), and that some greenstone/ophiolite terranes were produced through the combined effects of the two processes. Furthermore, neither the island arc nor the mantle plume model can account for the structure and composition of mature continental crust which is differentiated and chemically modified by convergent margin magmatism.
This differentiation and modification is required to explain the seismic velocity structure and incompatible element enrichment of mature continental crust.

Although the method of initial crustal extraction has not changed drastically over time, there has been a modest change in initial crustal thicknesses. As mantle temperatures declined, the average crustal thickness of oceanic plateaus/hotspots decreased from $40 \mathrm{~km}$ in the Archean, to $35 \mathrm{~km}$ in the Early Proterozoic, to $30 \mathrm{~km}$ in the post $1.8 \mathrm{Ga}$ era. In contrast to the modest secular change in the thickness and composition of crust created at plumes, there has been a radical secular change in the composition of arc magmatism. Therefore, we attribute most of the secular evolution of continental crustal composition to an evolution in the composition of continental arc magmatism, which rapidly alters newly accreted crust.

Our inference from seismic data that continents evolve from accreted oceanic plateaus is consistent with geochemical and structural evidence that many Precambrian cratons and Phanerozoic terranes originated as oceanic plateaus. Nevertheless, many questions remain. We have modelled the initial crustal thickness of newly accreted continental crust, whereas our seismic data set records the crustal thickness of present-day continental crust. Therefore, the ocean plateau model for initial continental crustal extraction needs much more integrated geochemical, structural, and geophysical work before it can be regarded as valid.

Acknowledgments. We thank Paul Hoffman, Sarah Hoffman, William Menke, and Roberta Rudnick for helpful discussions and Ron Mandel for comments on the paper. We also thank Sarah Hoffman for editing. LDEO Contribution 5329 .

\section{References}

Abbott, D., L. Burgess, J. Longhi, and W. H. F. Smith, An Empirical Thermal History of the Earth's Upper Mantle, J. Geophys. Res., 99, 13,835-13,850, 1994a.

Abbott, D. H., R. Drury, and W. H. F. Smith, The Flat to Steep Transition in Subduction Style, Geology, 22, 937940, 1994b.

Abbott, D. H., and W. H. Menke, Length of the global plate boundary at $2.4 \mathrm{Ga}$, Geology, 18, 58-61, 1990.

Arndt, N. T., and E. G. Nisbet, What is a komatiite?, in Komatiites, edited by N. T. Arndt and E. G. Nisbet, pp. 19-27, Allen and Unwin, Winchester, Mass., 1982.

Ashwal, L. D., and K. Burke, African lithospheric structure, volcanism, and topography, Earth Planet. Sci. Lett., 96, 8-14, 1989.

Beard, J. S., and F. Barker, Petrology and tectonic significance of gabbros, tonalites, shoshonites, and anorthosites in a late Paleozoic arc-root complex in the Wrangellia Terrane, J. Geology, 97, 667-683, 1989.

Beloussov, V. V., N. I. Pavlenkova, and A. V. Egorkin, Geophysical Models of the Territory of the USSR, 224 pp., Nauka, Moscow, 1991.

Ben-Avraham, Z., A. Nur, D. Jones, and A. Cox, Continental accretion: From oceanic plateaus to allochthonous terranes, Science, 213, 47-54, 1981. 
Bennett, V. C., and D. J. DePaolo, Proterozoic crustal history of the western United States as determined by neodymium isotopic mapping, Geol. Soc. Am. Bull., 99, 674-685, 1987.

Bickle, M. J., Implications of melting for stabilization of the lithosphere and heat loss in the Archean, Earth Planet. Sci. Lett., 80, 314-324, 1986.

Bickle, M. J., E. G. Nisbet, and A. Martin, Archean greenstone belts are not oceanic crust!, J. Geol., 102, 121-138, 1994.

Blenkinsop, T. G., et al., Ensialic origin for the Ngezi group, Belingwe greenstone belt, Zimbabwe, Geology, 21, 1135$1138,1993$.

Bogdonava, S. V., and E. V. Bibikova, The "Saamian" of the Belmorian Mobile Belt: New geochronological constraints, Precambrian Res., 64, 131-152, 1993.

Boher, M., W. Abouchami, A. Michard, F. Albarede, and N. T. Arndt, Crustal growth in West Africa at $2.1 \mathrm{Ga}, J$. Geophys. Res., 97, 345-369, 1992.

Borg, S. G., and D. J. DePaolo, Laurentia, Australia, and Antarctica as a Late Proterozoic supercontinent: Constraints from isotopic mapping, Geology, 22, 307-310, 1994.

Box, S. E., and W. W. Patton, Igneous history of the Koyukuk Terrane, Western Alaska: Constraints on the origin, evolution and ultimate collision of an accreted island arc terrane, J. Geophys. Res., 94, 15,843-15,867, 1989.

Brouxel, M., and H. Lapierre, Geochemical study of an early Paleozoic island-arc-back-arc basin system. Part 1: The Trinity Ophiolite (northern California), Geol. Soc. Am. Bull., 100, 1111-1119, 1988.

Bruce, R. M., E. P. Nelson, and S. G. Weaver, Effects of synchronous uplift and intrusion during magmatic arc construction, Tectonophysics, 161, 317-329, 1989.

Campbell, I. H., and R. W. Griffiths, The changing nature of mantle hotspots through time: implications for the chemical evolution of the mantle, J. Geol., 92, 497-523, 1992.

Campbell, I. H., R. W. Griffiths, and R. I. Hill, Melting in an Archaean mantle plume: heads it's basalts, tails it's komatiites, Nature, 339, 697-699, 1989.

Card, K. D., A review of the Superior Province of the Canadian Shield, a product of Archean accretion, Precambrian Res., 48, 99-156, 1990.

Cattell, A. C., and R. N. Taylor, Archaean basic magmas, in Early Precambrian Basic Magmatism, edited by R. P. Hall and D. J. Hughes, pp. 11-39, Chapman and Hall, New York, 1990.

Cloos, M., Lithospheric buoyancy and collisional orogenesis: Subduction of oceanic plateaus, continental margins, island arcs, spreading ridges, and seamounts, Geol. Soc. Am. Bull., 105, 715-737, 1993.

Condie, K. C., Geochemical changes in basalts and andesites across the Archean-Proterozoic boundary: identification and significance, Lithos, 23, 1-18, 1989.

Dalziel, I. W. D., and R. D. Forsythe, Andean evolution and the terrane concept, in Tectonostratigraphic Terranes of the Circum-Pacific Region, 1, edited by D. G. Howell, pp. 565-581, Circum-Pacific Council for Energy and Mineral Resources, Houston, Texas, 1985.

Davies, J. H., and M. J. Bickle, A physical model for the volume and composition of melt produced by hydrous fluxing above subduction zones, Phil. Trans. R. Soc. Lond., A335, 355-364, 1991.

Davis, W. J., and E. Hegner, Neodymium isotopic evidence for tectonic assembly of late Archean crust in the Slave Province, northwest Canada, Contrib. Mineral. Petrol., 111, 493-504, 1992.
De Witt, M. J., et al., Formation of an Archean continent, Nature, 357, 553-562, 1992.

Defant, M. J., et al., Andesite and dacite genesis via contrasting processes: the geology and geochemistry of $\mathrm{El}$ Valle Volcano, Panama, Contrib. Mineral. Petrol., 106, 309-324, 1991.

Desrochers, J. P., C. Hubert, J. N. Ludden, and P. Pilote, Accretion of Archean oceanic plateau fragments in the Abitibi greenstone belt, Geology, 21, 451-454, 1993.

Dostal, J., C. Dupuy, and R. Caby, Geochemistry of the Neoproterozoic Tilemsi belt of Iforas (Mali, Sahara); a crustal section of an oceanic island arc, Precambrian Res., 65, 55-69, 1994.

Downes, H., The nature of the lower continental crust of Europe: petrological and geochemical evidence from xenoliths, Phys. Earth Planet. Int., 79, 195-218, 1993.

Drummond, M. S., and M. J. Defant, A model for trondjhemite-tonalite-dacite genesis and crustal growth via slab melting: Archean to modern comparisons, J. Geophys. Res., 95, 503-521, 1990.

Durrheim, R. J., and W. D. Mooney, Archean and Proterozoic crustal evolution: evidence from crustal seismology, Geology, 19, 606-609, 1991.

Fyfe, W. S., Hot spots, magma underplating, and modification of continental crust, Can. J. Earth Sci., 30, 908-912, 1993.

Fyson, W. K., and H. Helmstaedt, Structural patterns and tectonic evolution of supracrustal domains in the Archean Slave Province, Canada, Can. J. Earth Sci., 25, 301-315, 1989.

Galer, S. J. G., Interrelationships between continental freeboard, tectonics and mantle temperatures, Earth Planet. Sci. Lett., 105, 214-228, 1991.

Gorbatschev, R., and S. Bogdonava, Frontiers in the Baltic Shield, Precambrian Res., 64, 3-21, 1993.

Grocott, J., M. Brown, R. D. Dallmeyer, G. K. Taylor, and P. J. Treloar, Mechanisms of continental growth in extensional arcs: An example from the Andean plate-boundary zone, Geology, 22, 391-394, 1994.

Haydoutov, I., Precambrian ophiolites, Cambrian island arc, and Variscan suture in the South Carpathian-Balkan region, Geology, 17, 905-908, 1989.

Helmstaedt, H. H., and D. J. Scott, The Proterozoic Ophiolite Problem, in Proterozoic Crustal Evolution, Developments in Precambrian Geology, 10, edited by K. C. Condie, pp. 55-95, Elsevier, Amsterdam, 1992.

Hickey, R. L., and F. A. Frey, Geochemical characteristics of boninite series volcanics, Geochim. Cosmochim. Acta, 46, 2099-2115, 1982.

Hoffman, P. F., Precambrian geology and tectonic history of North America, in The Geology of North America-An Overview, $A$, edited by A. W. Bally and A. R. Palmer, pp. 447-512, Geol. Soc. Amer., Boulder, 1989a.

Hoffman, P. F., Speculations on Laurentia's first gigayear $(2.0$ to $1.0 \mathrm{Ga})$, Geology, $17,135-138,1989 \mathrm{~b}$.

Hoffman, P. F., On accretion of granite-greenstone terranes, in Nuna Conference on Greenstone Gold and Crustal Evolution, edited by F. Robert et al., pp. 32-45, Geological Association of Canada Mineral Deposits Division, Val D'Or, 1990.

Hoffman, P. F., Did the breakout of Laurentia turn Gondwanaland inside-out?, Science, 252, 1409-1412, 1991.

Holbrook, W. S., W. D. Mooney, and N. I. Christensen, The seismic velocity structure of the deep continental crust, in Lower Continental Crust, edited by D. M. Fountain, R. Arculus and R. Kay, pp. 1-43, Elsevier, Amsterdam, 1992. Isachsen, C. E., and S. A. Bowring, Evolution of the Slave craton, Geology, 22, 917-920, 1994. 
Jackson, S. L., J. A. Fyon, and F. Corfu, Review of the Archean supracrustal assemblages of the southern Abitibi greenstone belt in Ontario, Canada: products of microplate interaction within a large-scale plate-tectonic setting, Precambrian Res., 65, 183-205, 1994.

Kimura, G., J. N. Ludden, J. P. Desrochers, and R. Hori, A model of ocean-crust accretion for the Superior province, Canada, Lithos, 30, 337-355, 1993.

Kincaid, C., and C. W. Gable, Dynamical interaction between upper mantle plumes and a spreading ridge: twodimensional experiments (abstract), Eos Trans. AGU, 73, $582,1992$.

Klein, E. M., and J. L. Karsten, Ocean ridge basalts with convergent margin geochemical affinities from the southern Chile Ridge (abstract), Eos Trans. $A G U, 75,742$, 1994.

Klein, E. M., and C. H. Langmuir, Global correlations of ocean ridge basalt chemistry with axial depth and crustal thickness, J. Geophys. Res., 92, 8089-8115, 1987.

Kroenke, L., et al., Introduction, in Proc. Ocean Drill. Progr., Init. Reports, 130 , edited by L. Kroenke, W. H. Berger and T. R. Janeck, pp. 5-9, Deep Sea Drilling Project, College Station, Texas, 1991.

Kusky, T. M., Accretion of the Archean Slave Province, Geology, 17, 63-67, 1989.

Kusky, T.M., Structural development of an Archean Orogen, Western Point Lake, Northwest Territories, Tectonics, 10, 820-841, 1991.

Kusky, T. M., and W. S. F. Kidd, Remnants of an Archean oceanic plateau, Belingwe greenstone belt, Zimbabwe, Geology, 20, 43-46, 1992.

Langmuir, C. H., E. M. Klein, and T. Plank, Petrological constraints of mid-ocean ridge basalts: Constraints on melt generation beneath ocean ridges, in Mantle Flow and Melt Generation at Mid-Ocean Ridges, 71, edited by J. P. Morgan, D. K. Blackmun and J. M. Sinton, pp. 183-280, AGU, Washington, 1992 .

Larson, R. L., Geological consequences of superplumes, Geology, 19, 963-966, 1991.

Mahoney, J. J., M. Storey, R. A. Duncan, K. J. Spencer, and M. Pringle, Geochemistry and geochronology of leg 130 basement lavas: Nature and origin of the Ontong Java plateau, in Proc. Ocean Drill. Progr., Sci. Results, 130, edited by W. H. Berger, L. W. Kroenke and L. A. Mayer, pp. 3-22, Ocean Drilling Program, College Station, Texas, 1992.

Mahoney, J. J., M. Storey, R. A. Duncan, K. J. Spencer, and M. Pringle, Geochemistry and Age of the Ontong Java Plateau, in The Mezozoic Pacific: Geology, Tectonics and Volcanism, 77, edited by M. S. Pringle, W. W. Sager and S. Stein, pp. 233-261, AGU, Washington, D.C., 1993.

Martin, H., The mechanisms of petrogenesis of the Archaean continental crust-Comparison with modern processes, Lithos, 30, 373-388, 1993.

McCulloch, M. J., The role of subducted slabs in an evolving Earth, Earth Planet Sci. Lett., 115, 89-100, 1993.

McCulloch, M. T., Sm-Nd isotopic constraints on the evolution of Precambrian crust in the Australian continent, in Proterozoic Lithospheric Evolution, Geodynamics Series, 17, edited by A. Kroner, pp. 115-130, AGU, Washington, D. C., 1987.

McDermott, F., N. B. W. Harris, and C. J. Hawkesworth, Crustal reworking in southern Africa: constraints from Sm-Nd isotope studies in Archaean to Pan-African terrains, Tectonophysics, 161, 257-270, 1989.

McKenzie, D., and M. J. Bickle, The volume and composition of melt generated by extension of the lithosphere, $J$. Petrol., 29, 625-679, 1988.
Meissner, R., The Continental Crust: A Geophysical Approach, 426 pp., Academic Press, London, 1986.

Mooney, W. D., and L. W. Braile, The seismic structure of the continental crust and upper mantle of North America, in The Geology of North America-an Overview, A, edited by A. W. Bally and A. R. Palmer, pp. 39-52, Geol. Soc. Amer., Boulder, 1989.

Naqvi, S. M., and J. J. W. Rogers, Precambrian Geology of India, Oxford Monographs on Geology and Geophysics, 6, 223 pp., Clarendon Press, New York, 1987.

Padgham, W. A., and W. K. Fyson, The Slave Province: a distinct Archean craton, Can. J. Earth Sci., 29, 20722086, 1992.

Pallister, J. S., R. J. Budahan, and B. L. Murchey, Pillow basalts of the Angayucham Terrane: oceanic plateau and island crust accreted to the Brooks Range, J. Geophys. Res., 94, 15,901-15,923, 1989.

Patchett, P.J., Isotopic Studies of Proterozoic crustal growth and evolution, in Proterozoic Crustal Evolution, 10, edited by K. C. Condie, pp. 361-382, Elsevier, Amsterdam, 1992.

Pearce, J. A., et al., Boninite and harzburgite from Leg 125 (Bonin-Mariana forearc): A case study of magma genesis during the initial stages of subduction, in Proc. Ocean Drill. Progr., Sci. Results, 125, edited by P. Fryer, J. A. Pearce and L. B. Stokking, pp. 623-659, National Science Foundation, Washington, D. C., 1992.

Pearcy, L. G., S. M. DeBari, and N. H. Sleep, Mass balance calculations for two sections of island arc crust and implications for the formation of continents, Earth Planet. Sci. Lett., 96, 427-442, 1990.

Perfit, M. A., et al., Geochemistry of volcanic rocks from the Woodlark Basin: Addressing the questions of ridge subduction and a reversal in the polarity of subduction, in Marine Geology, Geophysics, and Geochemistry of the Woodlark Basin-Solomon Islands Region, 7, edited by B. Taylor and N. F. Exon, pp. 113-154, Circum-Pacific Council for Energy and Mineral Resources, 1987.

Plank, T., and C. H. Langmuir, An evaluation of global variations in the major element chemistry of arc basalts, Earth Planet. Sci. Lett., 90, 349-370, 1988.

Poidevin, J. L., Boninite-like rocks from the Paleoproterozoic greenstone belt of Boguin, Central African Republic: geochemistry and petrogenesis, Precambrian Res., 68, 97113, 1994.

Prodehl, C., Structure of the Earth's crust and upper mantle, in Geophysics of the solid Earth, the Moon and the planets, $11 A$, edited by K. Fuchs and H. Soffel, pp. 97206, Springer-Verlag, Berlin, 1984.

Richards, M. A., D. L. Jones, R. A. Duncan, and D. J. DePaolo, A mantle plume initiation model for the Wrangellia flood basalt and other oceanic plateaus, Science, 254, 263-267, 1991.

Richardson, S. H., J. J. Gurney, A. J. Erlank, and J. W. Harris, Origin of old diamonds in enriched mantle, Nature, 310, 198-202, 1984.

Richardson, S. H., J. W. Harris, and J. J. Gurney, Three generations of diamonds from old continental mantle, $\mathrm{Na}$ ture, 366, 256-258, 1993.

Rosen, O. M., K. C. Condie, L. M. Natapov, and A. D. Nozhkin, Archean and Early Proterozoic Evolution of the Siberian Craton: A Preliminary Assessment, in Archean Crustal Evolution, edited by K. C. Condie, pp. 411-459, Elsevier, Amsterdam, 1994.

Rudnick, R. L., and K. L. Cameron, Age diversity of the deep crust in northern Mexico, Geology, 19, 1197-1200, 1991.

Ruiz, J., Xenoliths in Proterozoic Crust: Evidence for Reworking of the Lower Crust, in Proterozoic Crustal Evo- 
lution, 10, edited by K. C. Condie, pp. 361-382, Elsevier, Amsterdam, 1992.

Salisbury, M. H., and D. M. Fountain, Exposed Cross-Sections of the Continental Crust, 586 pp., Kluwer Academic, Dordrecht, 1990.

Schandelmeier, H., et al., Late Proterozoic magmatism in the Nakasib suture, Red Sea Hills, Sudan, J. Geol. Soc. London, 151, 485-497, 1994.

Sleep, N. H., Archean plate tectonics: what can be learned from continental geology?, Can. J. Earth Sci., 29, 20662071, 1992.

Smith, T. E., Volcanic rocks of Early Proterozoic Greenstone Belts, in Proterozoic Crustal Evolution, 10, edited by K. C. Condie, pp. 1-54, Elsevier, Amsterdam, 1992.

Smith, W. H. F., Marine geophysical studies of seamounts in the Pacific Ocean, Ph.D. thesis, 245 pp., Columbia, 1990.

Smith, W. H. F., On the accuracy of digital bathymetric data, J. Geophys. Res., 98, 9591-9603, 1993.

Stein, M., and A. W. Hofmann, Mantle plumes and episodic crustal growth, Nature, 372, 63-68, 1994.

Storey, M., J. J. Mahoney, L. W. Kroenke, and A. D. Saunders, Are oceanic plateaus sites of komatiite formation?, Geology, 19, 376-379, 1990.

Sylvester, P. J., and K. Attoh, Lithostratigraphy and Composition of $2.1 \mathrm{Ga}$ Greenstone Belts of the West African Craton and Their Bearing on Crustal Evolution and the Archean-Proterozoic Boundary, J. Geology, 100, 377-393, 1992.

Taylor, S. R., and S. M. McLennan, The composition and evolution of the continental crust: rare earth element evidence from sedimentary rocks, Phil. Trans. Roy. Soc., A301, 381-399, 1981.

Taylor, S. R., and S. M. McLennan, The Continental Crust: Its Composition and Evolution, 312 pp., Blackwell Scientific Publications, Oxford, 1985.

Toft, P. B., D. V. Hills, and S. E. Haggerty, Crustal evolution and the granulite to eclogite transition in xenoliths from kimberlites in the West African Craton, Tectonophysics, 161, 213-231, 1989.

Vail, P. R., and R. M. Mitchum, Global Cycles of Relative Changes of Sea Level from Seismic Stratigraphy, in Geological and Geophysical Investigations of Continental Margins, 29, edited by J. S. Watkins, L. Montadert and P. W. Dickerson, pp. 469-472, American Assoc. of Petroleum Geologists, 1979.

Van Schmus, W. R., et al., Transcontinental Proterozoic Provinces, in Precambrian, Conterminous U.S., C-2, edited by W. R. V. Schmus and M. E. Bickford, pp. 171-334, Geol. Soc. Am., Denver, 1993.

Wellman, P., Development of the Australian Proterozoic crust as inferred from gravity and magnetic anomalies, Precambrian Res., 40/41, 37-60, 1988.

Wendlandt, E., D.J. DePaolo, and S.W. Baldridge, Nd and Sr Isotopic Chronostratigraphy of Colorado Plateau lithosphere, Earth Planet. Sci. Lett., 116, 23-43, 1993.

White, R. S., and D. P. MacKenzie, Magmatism at rift zones: The generation of volcanic continental margins and flood basalts, J. Geophys. Res., 94, 7685-7729, 1989.

Zhang, C., Z. Mingguo, M. B. Allen, A. D. Saunders, G. R. Wang, and X. Huang, Implications of Paleozoic ophiolites from Western Junggar, NW China, for tectonics of central Asia, J. Geol. Soc. London, 150, 551-561, 1993.

Zhang, Y. S., and T. Tanimoto, High-Resolution Global Upper Mantle Structure and Plate Tectonics, J. Geophys. Res., 98, 9793-9823, 1993.

D. Abbott, Lamont-Doherty, Earth Observatory, Palisades, NY 10964. (e-mail: dallas@ldeo.columbia.edu)

W. Mooney, U.S. Geological Survey, Menlo Park, CA 94025.

(Received June 20, 1994; revised December 27, 1994; accepted January 23, 1995.) 